\title{
How far is World Champion from World Class? Institutional effects on a Brazilian non-profit sports organization
}

\author{
Ivan Rodrigo Rizzo Dias ${ }^{\dagger}$ \\ ESPM \\ George Bedinelli Rossi ${ }^{\Omega}$ \\ ESPM; EACH-USP
}

\begin{abstract}
The objective of this research is to identify the main factors for the internationalization of Brazilian soccer teams via the strategic networks and institutional view approaches. The literature review unveils that ties and connections to the access and acquisitions of inimitable resources, learning races and being a leader or occupying an important position in a network are the main factors for the network formation to achieve internationalization. We adopted the single case study method, and data collection was done by in depth-interviews with ten key respondents. The main findings revealed that resource acquisition capabilities, the organization's size, brand and image reputation and institutional environment are relevant factors for the internationalization of a firm by networks. As a theoretical contribution, firms that have strong brand and image reputation with resources that will strength network are an important factor for a firm entering a network or developing one. Regarding managerial perspective, a main contribution is to propose a sequence of factors to be used in a specific way.
\end{abstract}

Keywords: Networks; Soccer Team; Brand; Reputation.

Received in 04/27/2016; revised in 06/07/2016; accepted in 07/14/2016; divulgued in 01/23/2017.

*Author for correspondence:

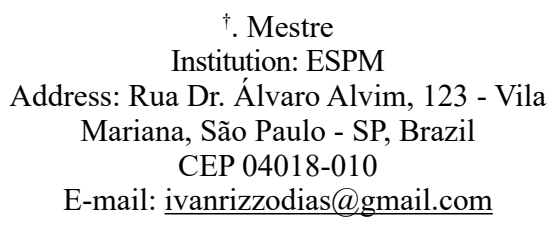

$\dagger$. Mestre Institution: ESPM Address: Rua Dr. Álvaro Alvim, 123 - Vila Mariana, São Paulo - SP, Brazil CEP 04018-010

E-mail: ivanrizzodias@gmail.com

\author{
$\Omega$. Doutor \\ Institution: ESPM; EACH-USP \\ Address: Rua Catanduva, 119, \\ São Paulo, SP, Brazil \\ CEP 01246-060 \\ E-mail: george.rossi@gmail.com
}

Note from the Editor: The article was accepted by Bruno Felix. 


\section{INTRODUCTION}

he global importance of soccer can be quantified by its popularity. The 2014 FIFA World
Cup in Brazil reached a global domestic television audience of approximately3.2 billion
viewers, breaking a lot of TV audience records in important markets such as in the United States and Germany. A total of 1.013 billion people watched the final match between Argentina and Germany, an increase of $12 \%$ on 2010 World Cup (FIFA, 2015) leading soccer as an international product influencing businesses on a global scale (RATTEN, 2011).

Also, as globalization has been an important issue for commercial firms in contemporary society and many corporations have adopted global approaches to achieve a variety of markets to increase performance (ZHOU; TENG; POON, 2008), this same way has been adopted by soccer teams as Barcelona among others (MILLAR; DOHERTY, 2016).

The sports industry has specific characteristics that differs from other industries, such as simultaneous production and consumption, synchronized co-operation and competition, monopolistic bargaining and territorial rights, revenue sharing, vicarious identification of consumers, ephemeral experience and, most importantly, the uncertainty of games outcomes (ZHANG; KIM; PIFER, 2014).

Most sports researchers try to explain sports and teams popularity, internationalization and global importance to businesses through very different approaches including: motivators for sports spectatorships (TRAIL; KIM, 2011), brand (PYUN et al., 2011), team personality and geographic personality (AIKEN et al., 2013), athlete endorsement (CHANG et al., 2014), patriotism and national athletes (ROCHA; FINK, 2015), team reputation (JANG; JAE KO; CHAN-OLMSTED, 2015), sponsorship (HENSELER et al, 2007), leadership (PARENT; SÉGUIN, 2008), and cost performance (BARROS et al., 2014) among other approaches.

However, the literature review was not able to explain sports teams' success by its strategies as a firm. In this path for soccer's teams internationalization, as commercial firms do, aiming to increase its sports and financial performance, none can do it isolated from others business (as broadcasting or sporting goods companies). Internationalization must be seen as network process instead an atomistic view (JARRILO, 1988).

Neither strategic approach nor sports management consider the importance of institutions as an important factor for firm's performance. In order to explain the internationalization of soccer teams, we adopted the institutional view and strategic networks approaches to propose a performance framework on internal capabilities of a non-profit sports organizations (NPSO) and its capacity to manage resources such as top players, infra-structure and institutional environment. 
The objective of this research is to identify the main factors for the internationalization of a Brazilian soccer team through sports management, strategic networks and institutional view approaches. This article contributes to the sports management theory/concepts by incorporating the influence of institutional environments and Networks to the performance of a NPSO. For that, an exploratory qualitative research was developed as a single case study with a Brazilian NPSO, Corinthians, with field data collection by interviews and secondary data, purposeful selection of interviewees and relational content analysis for data.

The paper is structured as follows. First, we present a brief review on Sports Management, Strategic Network and Institutional View. Then, we present method, findings and discussions, final considerations, limitations and recommendations to both academics and practitioners.

\section{LITERATURE REVIEW}

\section{Sports Management.}

The sports industry has specific characteristics that differs it from other industries, such as simultaneous production and consumption, synchronized co-operation and competition, monopolistic bargaining and territorial rights, revenue sharing, vicarious identification of consumers, ephemeral experience and, most importantly, uncertainty of game outcomes (ZHANG; KIM; PIFER, 2014).

Sports as an international product influence businesses on a global scale, and different academic areas as Sports Internationalization and marketing among others have investigated sports management (RATTEN, 2011).

Sports have internationalized due to its cross-cultural appeal to different people around the globe through technologies such as broadcasting and internet. Both of these technologies, mainly the former, allow people to watch several sports on different locations whenever they wish to (RATTEN, 2011).

For Chadwick (2007) the bigger the number of large companies seeing sports as a way to manage their products and services, the more attention will be given as to how sports become global. . Some sports firms, including teams, have increased their popularity using global medias in different formats and communications (CLARKE; MANNION, 2006) diversifying customers and fans increasing firms' awareness on globalization benefits.

In this sense, Marketing has an important role for sports firms to achieve globalization. Sports marketing is about sports events, equipment, and facilities promoting products and services, with sports events and athletes being quite important to international business favoring connections between sports and businesses (GOLDMAN; JOHNS, 2009). And, the increasing technological 
advance in communications allows sports firms to be more connected with fans and customers by social networks and media in an international scale (COOKE; BUCKLEY, 2008).

The increasing fan base in international or global scale by communications medias such as broadcasting and the Internet has been driven by branding efforts by sports clubs (CUTLER, 2009). Sports teams such as Manchester United (LEWIS, 2001) and Barcelona (BERRONE, 2011) have created worldwide fan bases leading these teams to be branded as cultural phenomena. This has increased their brands and partners' reputation around the world generating more revenues from ticket and merchandise sales (MUNIZ; O`GUINN, 2001).

For Jang et al. (2015), reputation is a very important and valued intangible asset that has a major impact on the firms' success. Dowling (2004) asserts that a positive reputation enhances the firm's financial performance and equity, reputation is related to long term success (HILL; VINCENT, 2006) and it influences trust (KEH; XIE; 2009) and satisfaction (WALSH; BEATTY, 2007). Ross et al. (2009) assert that team reputation and success are related to the team's on-field performance that is, winning games and championships.

For Lanza et al. (2016) the team's on-field performance depends on its resources (athletes) and resource orchestration. These resources are more valuable the more experienced they are. This long term arrangement leads to tacit knowledge since each athlete knows how each one plays the game increasing the team's performance facilitating communication amongst themselves (GROYSBERG et al, 2008) which for Lanza et al. (2016) is an important factor to increase the team's on-field performance. Therefore, the most important resource for a team is the athlete, which is also the most expensive (DI MININ et al., 2013).

Concerning the team's on-field success, another important factor is regarding the quality of the resource (athletes) defined as the number of matches played during the season, the number of seasons played and the importance of the championship or divisions such as the A, B, C or D series, and so forth (LANZA et al., 2016).

High quality athletes are important because they can drive the team to victories and titles which contributes to a team's reputation (DIMININ et al., 2013). For this result teams have to spend more and more towards hiring and training athletes, resulting in an expenditure escalation, leading to the necessity of new revenues from media rights and merchandising (BARONCELLI, LAGO, 2007).

Parent and Foreman (2007) assert that there are internal capabilities that can be split into three dimensions, independent but related to each other: political/networking skills, business/ management skills and sports skills.

Political/networking skills refers to the ability of having and maintaining personal and professional relationships with several stakeholders, "negotiating and managing the internal 
and external political 'wheelings and dealings,' and understanding the needs and wants of these stakeholders, whether they were political/government stakeholders or nongovernmental."

Business/management skills involves basic management skills such "as strategic planning, writing a business plan, financial skills, communication skills, and human resources management (including motivating employees and volunteers).

Sports Skills refers to the technical ability needed from the organization for the sport to be showcased. This dimension is similar to what Lanza, Simone and Bruno (2015) called resource orchestration, the process of acquiring, accumulating and divesting resources as resource restructuring, in the present case, the ability to maintain a competitive cast of players.

This session dealt with the traditional literature about sports management, but it does not link with strategic network. The next session presents a literature review on strategic networks.

\section{STRATEGIC NETWORKS}

As it happens to different kinds of firms, the internationalization of a football team rarely occurs in a single form. Therefore, the football team must have the right partnerships. The atomistic approach, when a single firm competes as an autonomous unit for profits in non-personal market, that is the least useful way to analyze organizations that are more and more related to professional and social networks, considering the trade exchange relationship with other organizations (ZAHEER; BELL, 2005). Moreover, in this view the macro-environment becomes a very important factor in the firms' competitiveness (PHELPS, 2010).

This section presents a review on each of the five traditional sources of differential returns for a firm in strategic networks: industrial structure, positioning in the industry, imperfect imitation of resources and competencies, contracts and coordination costs, networks dynamics and consequences; and, Institutional view and Networks.

\section{Industrial Structure}

To better understand industrial structure, the network perspective allows viewing firms in the industrial structure as a resource and an information network among other flows (CRESPO; SUIRE; VICENTE, 2014). In this sense, Galaskiewicz and Zaheer (1999) present three relationship types: network structures, which are the relationship patterns inside the industry; firms associated to network, which compose the network considering factors such as identity, status, resources accesses; and, ties modalities, that are a set of norms and standards ruling network behavior by formal contracts. More importantly, are the informal understandings among network firms (ZAHEER; GÖZÜBÜYÜK; MILANOV, 2010). 


\section{Positioning in the Industry}

The analysis of the internal structure of the traditional industry reveals that firms are not homogenous, however, some are more similar to others when forming strategic groups or groups of firms. These groups are identified by similarities such as scale, products and services, prices, quality, technology, consumers' services among others. Strategic groups frontiers can be difficult to overcome due to mobility barriers (ZAHEER et al., 2010), and have been used to explain different performances inside the industry (MAS $\square$ RUIZ; RUIZ $\square$ MORENO, 2011).

A more interesting approach replacing strategic groups is provided by strategic networks regarding relationships and interactions between firms to identify groupings inside the industry, or clicks or strategic blocks, defined as firms groups that create alliances (CRESPO et al., 2014). Firms inside a block are locked in to cooperate with network firms and are locked out to cooperate with firms in others blocks (VINCENT et al., 2014).

This approach offers a view of the entry and exit barriers for firms in a network on grounds that the ties between the firms in the network can provide, at the same time, entry barriers to a firm outside the network trying to enter it and exit barriers for firms in the network(BRAMOULLÉ et al., 2014; CHRISTAKIS et al., 2010). In addition, a firm that optimizes the group competence can achieve a leading position (playing a role termed as server), and in this sense every firm can focus on its own main competences optimizing size and efficiency of other network firms (SOOSAY, 2016).

\section{Imperfect resources and competencies imitation}

The Resource Based View (RBV) asserts that resources that are owned or controlled by one firm have the potential to provide a sustainable competitive advantage when resources are not easily imitable nor substitutable (BARNEY et al., 2011; KRAAIJENBRINK, 2010); in this sense, a firm searches for internal valuable and inimitable resources (KOZLENKOVA et al., 2014).

For McWilliams and Siegel (2011), a strategic network itself is an inimitable and a nonsubstitutable resource and used as a way to access inimitable resources and competences being in that sense a source of resources. Considering the RBV, as a source of inimitable resource generation that will create value, it is based on the relationships that the firm has in the network. This network allows accesses to critical environmental resources such as information, financing, goods and services and, since these resources are internalized into the organized network, they become inimitable and non-substitutable and thus, valuable (GULATI; LAVIE; MADHAVAN, 2011).

\section{Contracts and coordination costs}

The question of whether the company should make or buy a particular input or service presents broad and classic debate in the strategy literature. Research on this subject receives 
strong influence from the transaction cost perspective that emphasizes the dangers of contracts (WILLIAMSON, 2010).

Hierarchical governance structures should occur when there are chances of opportunism and transaction costs are high. On the other hand, market exchange should be favored when formal contracts (written) exist and are met and the transaction costs are low (TADELIS; WILLIAMSON, 2012).

According to Keller et al. (2011) a very important factor helping network formation is brand. Competitive benefits for firms are created when brands generate firms' image and reputation with the power of attracting and ensuring customer loyalty. In this sense, a positive brand image and reputation may help to increase network formation. Brand can contribute to network formation by reducing risk and uncertainty leading to a strategic proximity between firms and it can create competitive and economic advantage increasing firms relationships (SUNG; KIM, 2010). When the quality of a specific brand is hard to be measured or tested, usually it is replaced by the status that the brand represents (LANGE et al., 2011), as it happens to a soccer club that wins a championship (PAWLOWSKI; ANDERS, 2012).

\section{Networks dynamics and consequences}

Networks can also evolve endogenously. Ties formed or broken by any actor/agent do not only influence their own behavior in subsequent periods but also others with whom the actor was related to (MARIOTTI; DELBRIDGE, 2012). In the dynamics of when an agent forms a partnership, others follow this movement by creating a dense network. Other mechanisms for endogenous development include the path to information that each tie represents that has the potential to alter the structure of opportunities for a specific actor as much as when a new bond is formed or broken (GULATI; NICKERSON, 2008).

The dynamics of networks has several consequences for the network's firms; the most common effects are locked in and out and learning races. The first happens because in many situations, ties formed by a company impose restrictions on other companies. A company that forms a tie with another company, can no longer form other ties with other companies outside the network.

\section{THE INSTITUTIONAL VIEW}

Chassagnon (2011) asserts that an inter-organizational network must have at least some coordination properties as to impose norms and standards to regulate the interdependence among firms in a different way as individual coordination happens to an atomistic approach, and the attributes are not necessary intermediaries regarding markets and hierarchies approach, however, 
it does not need to be exclusive to a firm, but instead they have to be balanced with different intensities for each situation.

The new institutional view asserts that among all antecedents to a network formation, dependence to resources such as raw material, equipment and transactions are crucially important, but also as a source of legitimation (BARNEY et al., 2011). This perspective takes into account that relative efficiency and the easiness for creating cooperation networks is a function of different social institutions in which all relationships are in, including laws, banking, labor and the political system (MACKINNON, 2012).

Despite the research distance between institutional view and networks, Owen-Smith and Powell (2008) stated the existence of at least four main common ideas to these approaches and are indissoluble as the organizational field, institutional view, embeddedness and social capital.

Several research that associate strategic networks to social capital in organizational studies claim to highlight the need of evaluating a network as a function of the quality of its ties, such as its frequency, intensity, complexity and configuration among others. This thought extends to the need of analyzing whether such ties are direct or indirect (CARPENTER et al., 2012). The analyzes of such ties guarantees accesses to people who can provide mutual support to resources, which they can use and mobilize on their own connections.

Carpenter et al. (2012) assert that, as network agents are connected, it facilitates the emergence of standards and the maintenance of trust amongst network agents increases social capital. Borgatti and Halgin (2011) emphasize that networks with fewer ties but with redundant connections are more durable.

For Gulati, Lavie and Madhavan (2011) a firm's social connections is a guide to its interests for new network arrangements and are provided as opportunities to achieve the firm's objectives, it is anchored in the processes indicating the firm's entry in a new network structure. Concerning the strategic view, key points can be noticed by events sequence in a network, including the decision to enter or form a network, the partner choice, the network structure and how this will evolve in years ahead.

Strategic network and Institutional view don't usually investigate sports firms. This research fills this gap showing that even sports presenting different nature from traditional business can be analyzed by these two approaches. So, this paper combines Strategic Network and Institutional view, which is uncommon in both literature. Also, this paper shows that both approaches come together and cannot be seen as isolated from each one.

This article contributes to the sports management theory/concepts by incorporating institutional environment influence and Networks at a NPSO's performance. And, the objective 
of this research is to identify the main factors of internationalization for a Brazilian soccer team through the approaches of sports management, strategic networks and Institutional view.

\section{METHODS}

This is a qualitative research, as Auerbach and Silverstein (2003) assert, it allows the understanding of meanings of events, situations and actions in which individuals are embedded and, to investigate a phenomenon accordingly to respondents' opinions, and the phenomenon under investigations is Strategic Networks, and the action researched is Strategic Networks Formation and their performance in sports organizations.

In this sense, we conducted a case study, which according to Simons (1996) is the type of qualitative research that is more appropriate to evaluate the temporal and within-unit variation phenomenon (GERRING, 2004) under investigation, and for Swanborn (2010) another element to characterize a case is to consider that it must be contemporary - formation of strategic networks and its performance in sports.

The epistemological approach was Social Constructivism once truth is relative and is dependent on one's perspective (BAXTER, JACK, 2008).

Regarding the type of case study, we opted for the intensive type, which according to Swanborn (2010) and Hodgetts and Stolte (2012) allows the investigation of a phenomenon analyzing fewer individuals in a deeper analysis. Moreover, regarding the case level, we adopted a micro level with more than one actor, that allows the researcher to investigate the phenomenon with people and the relation of those people among each other (SWANBORN, 2010). The choice of this level of analysis is due to the choice of forming or entering a strategic network being a social process where the opinion of some influencing others (MERCIER; SPERBER, 2011).

While choosing a sample of specific cases from a given population is uncommon for theory building (since in general statistics sampling it is more likely), qualitative research based on theoretic sampling, where the cases are chosen by theory (GLASER; STRAUSS, 1967) to fulfill theoretical gaps or to identify categories to formalize the theory. The objective of theoretical sampling is to choose purposeful cases that are replicable and/or capable of extending the theory (SURI, 2011).

Therefore, this research is based on a theoretical sample and purposeful selection of people aiming to contribute to the analysis of formation of strategic networks and the performance of a specific organization - in the present case, a non-profit sports organization.

For this study, we chose a soccer club from São Paulo - Brazil, Sport Club Corinthians Paulista, that form networks with firms and institutions presented below. Corinthians, founded in 1910, affiliated to Federação Paulista de Futebol (FPF), which is affiliated to Confederação Brasileira de Futebol (CBF), affiliated to Fédération Internationale de Football Association (FIFA). 
These organizations have normative control over the ordinance of championships and are owners of several commercial rights over the competitions that they organize.

Under professional administration since early 2000, FIFA World Champion in 2012, Corinthians has a sporting goods supply agreement with the North American company Nike, broadcasting rights commercialized by Rede Globo de Televisão, sponsorship agreements with FEMSA, Inbev, Brazilian state-controlled bank Caixa Economica Federal, 106 branches of its soccer franchise called "Chute Inicial", more than 100 franchises of its licensed products called "Todo Poderoso", besides several partnerships with non-governmental organizations such as $\mathrm{AACD}$, and it participates on campaigns for cancer awareness, against slavery work, against child prostitution among many others (CORINTHIANS, 2014).

The type of sample of (1) is theoretical and by judgment (MARSHALL, 1996) within which the intention is to identify the decision maker for the formation of strategic networks and (2) homogenous, composed by actors that actively participated in the process of strategic networks formation from the beginning of the 2010 decade until 2015.

For the selection of the interviewees the option was for purposeful selection (SURI, 2011) once the objective of the research is to understand strategic networks formation and its implications in achieving performance (MARSHALL, 1996). We chose relevant actors for the case in study from inside the organization Corinthians, three journalists that are responsible for the sports industry content from the most relevant websites in Brazil and three international Corinthians' commercial partners with different types of contracts: licensing, sports goods supplier and one sponsor. The interviewees profile is presented in Table 1.

\section{Data collection and interviews}

The data collection was conducted through personal interviews. The total time with interviews was over 444 minutes and 105 pages transcribed.

The interviews were conducted in natural environment (KNOX, BURKARD, 2009) so the categories would not be biased. In the interviewees own work environment, the interviews were recorded and the questions were placed naturally during the sessions, when other subjects emerged. The main objective at this moment was to obtain broader descriptions of the investigated phenomenon through the perspective of the actors, in this case the process of entering a strategic network visa vis increment of performance, being the questions from a generalist to specific level.

After the data collection, the recordings were transcribed. Through content analysis, data was organized, condensed and labeled with the objective of obtaining the most relevant aspects for the general objective of the research (STRIJBOS et al, 2006). 
Table 1. Interviewees profile.

\begin{tabular}{|c|c|c|c|c|}
\hline Interviewee & Job Title & Date & $\begin{array}{l}\text { Duration } \\
\text { (minutes) }\end{array}$ & $\begin{array}{c}\text { Total number of pages } \\
\text { transcribed }\end{array}$ \\
\hline \multicolumn{5}{|l|}{ Corinthians } \\
\hline 1 & Marketing Vice President & $23 / 04 / 2015$ & $64: 00$ & 11 \\
\hline 2 & Commercial Manager & 06/07/2015 & 43:04 & 10 \\
\hline 3 & Marketing Manager & $06 / 07 / 2015$ & $55: 01$ & 14 \\
\hline 4 & Social Media Manager & $19 / 08 / 2015$ & $52: 40$ & 16 \\
\hline \multicolumn{5}{|l|}{ Journalists } \\
\hline 5 & Editor (Website \#1) & $13 / 05 / 2015$ & $37: 04$ & 9 \\
\hline 6 & Journalist (Website \#2) & $27 / 05 / 2015$ & $53: 15$ & 12 \\
\hline 7 & Journalist (Website \#3) & $12 / 05 / 2015$ & $27: 18$ & 6 \\
\hline \multicolumn{5}{|l|}{$\begin{array}{l}\text { Commercial } \\
\text { Partners }\end{array}$} \\
\hline 8 & Licensing Company's Marketing Vice President & $07 / 10 / 2015$ & $38: 27$ & 9 \\
\hline 9 & Sports Goods Soccer Manager & $15 / 09 / 2015$ & $49: 30$ & 12 \\
\hline \multirow[t]{2}{*}{10} & Sponsor Soccer Manager & 03/09/2015 & $24: 00$ & 6 \\
\hline & Total & & $444: 19$ & 105 \\
\hline
\end{tabular}

Source: Developed by the authors.

The following step was a test verification to guarantee that there was sufficient consistency in emerging codes. This was accomplished by the verification of two different researchers. For the validity of this research we adopted the steps suggested by Morse et al (2008) and Watt (2007): internal validity, interpretative validity and integrity. For parsimony, several techniques with the objective of avoiding misunderstandings regarding the use of a particular method were utilized (BASHIR et al., 2008).

From the theoretical references and interviewees, codification was done and presented in Table 2.

Table 2. Codification.

Code searched in interviews

Club's relevance and size, brand value as benchmark for partnerships.

Importance of top players of international reputation in the team

Winning relevant championships

Choice of commercial and relationship partners.

Relationship with CBF, FPF, CONMEBOL and FIFA

Relationship with press, supporters and influencers

Source: The authors.
Theoretical reference

Partnership, search for resources; Technology, scale, similarity among firms

Proprietary resources (valuable and inimitable).

Resources that provide access to other resources.

Relationship of organization with others

Hierarchy and markets, transactions history, trust and risks, cost reduction

Long term contracts, trust and changes and evolution in networks.

Formal institutional environment

Informal institutional environment 


\section{RESULTS AND DISCUSSION}

The main contribution of this study is to contextualize the Brazilian NPSO within the view of strategic management with that of strategic networks and with the institutional view.

We propose six dimensions and seven relations among them, as stated in figure 1 below.

The literature review presented three dimensions of internal capabilities proposed by Parent and Foreman (2007): political/networking skills, business/management skills and sports skills.

From the data collection a fourth organizational capability emerged: infrastructure/facilities, defined as the set of elements that facilitates the production of sports services, including elements as hotels, training fields, medical centers and others.

However, differently from Parent and Foreman (2007), the findings assert that these four dimensions are capable of influencing the NPSO sports performance, being its performance a main driver that affects the organization brand and therefore its reputation.

Although they appear as four different dimensions, our case study shows that a NPSO tries to balance them in order to achieve sports performance. When an organization is misbalanced in one of these skills, there is a great effort to counterbalance it by adding efforts on the other dimensions.

Based on the collected data and its validation, our research can assert seven propositions, stated below:

\section{P1: Resource acquisition of a NPSO influences its internal capacities}

Interviews stated that at a given point "Corinthians provided everything a player might consider important such as stability, good wages, infrastructure and medical facilities. The view

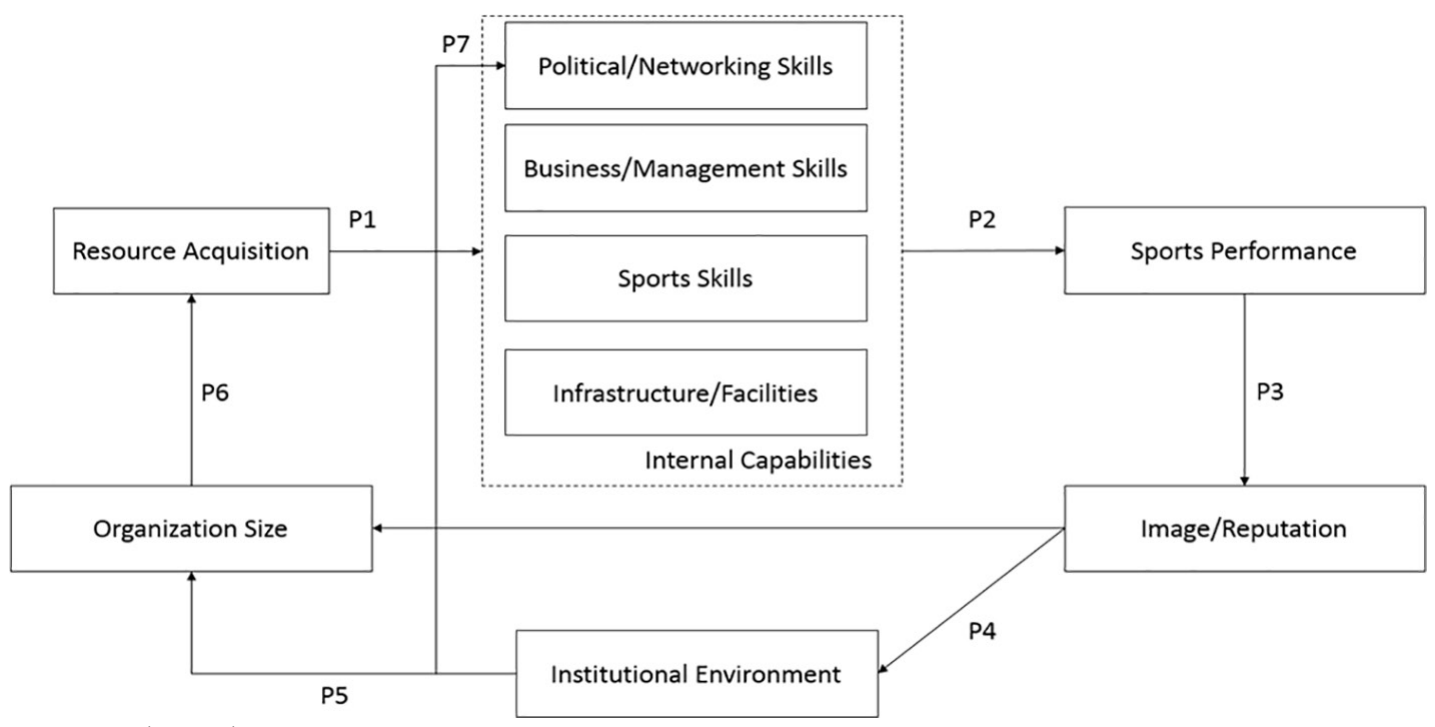

Source: The authors.

Figure 1. Performance Framework for NPSOs. 
was clear: to create a benefits package that could change anyone's mind who might be wondering whether they should come here." In another interview, it was said that "it was kind of lucky that we found out it was Peruvian National Day, we could use tools provided by our social media partners to celebrate with Guerrero (Peruvian player)."

P2: NPSO's internal capabilities are capable of influencing its performance.

The more efficient and effective in managing NPSO's internal capabilities, the probability of occurrence of superior sports performance increases. This reference can be also found in works such as Desbordes and Richelieu (2009) or Millar and Doherty (2016) however, known literature does not explicit these four dimensions and does not remark infrastructure as a key element on a NPSO's sports performance.

In the words of the sporting goods supplier: "Everything was done as planned, we were sold out. If you see it as a product life cycle, 2012 New Jersey was a hit. Corinthians communicated it very well. It is perfect when we watch something that has a start, a development and it works out perfectly well"'.

Or when a sponsor was comparing Corinthians with a competitor, the statement: "what another club represented in terms of medical treatment was surpassed by Corinthians ten years later. This allowed Corinthians to achieve something unthinkable before".

P3: NPSO's sports performance are capable of influencing its image.

The key issue here is that the NPSO's performance has the potential to reposition the organization within its network, which can allow it to access a new set of opportunities and resources with the same partners or new ones, and as a consequence, repositioning its status. Image and reputation, in this model, refers to how much the organization and its brands are known, how much its stakeholders are aware of its activities and results.

Since it is not possible to measure quality on services provided by an NPSO when it is champion, it is common to replace it by gains of its brand. One of Corinthians' commercial partners interprets it as the following: "to sell Corinthians when it is champion you don't have even to leave your house. The challenge is when the team is not helping".

However, it is not wrong to state that, the variety of opportunities has its limitations as an interviewee appears to be concerned about foreign audiences: "due to restrictions related to time zones, or even low interest about the Brazilian National League, the show remains mainly national, the whole system is inefficient to broadcast overseas".

\section{P4: NPSO's image is capable of influence the institutional environment}


By institutional environment we can refer to formal institutions such as Confederação Brasileira de Futebol (CBF) and Confederación Sudamericada de Fútbol (Conmebol), and as informal institutions as media groups, supporters, influencers, among others stakeholders.

When NPSO achieves sports performance, its relationship with institutional environment alters, increasing the amount of partners that intend to be on its network to benefit from and profit with the NPSO's new status. One of the interviewees stated: "if CBF is not in order, everything else will never be, at least to the eyes of the world". Another one asserted: "In Europe, the counting system for the number of victorious championships is only used if these are won in a sequence. hey only say double champion, when the titles are achieved in a row, meanwhile for us, it can be achieved at any given time".

P5: Institutional Environment is capable of influencing NPSO's size.

A NPSO's size can be measured by the amount and volume of interactions of its agents', however this volume of interactions or nodes are surrounded by uncertainty and embedded in formal and informal relations in the NPSO's environment.

For example, when comparing the size of Brazilian and Spanish Soccer League, one interviewee said, "the idea we have about Spain is that competition was killed with governmental help". On an additional approach, a Corinthians' manager said "if someone comes here, bankrupts the club but wins a championship he is not a bad guy, but a hero. Until we change way businesses are done, if the government doesn't intervene, priorities will always be crooked".

P6: NPSO's size affects its resource acquisition capacity.

For a NPSO, due to the sports industry's nature, resource acquisition is based on unknown gain expectancy and an expected level of uncertainty for partners, suppliers and stakeholders that are embedded in its network. Corinthians' Social Media manager guarantee's he has access to some social media tools that other companies must pay for because "if we use their social media, by their rules, with our size, the whole system feedbacks itself". The sports goods supplier asserted: "the company has this obsession to be attached to the greatest and the biggest, so Corinthians was the obvious choice. Only clubs with that great amount of supporters are we able to work with during good and bad times".

\section{P7: Institutional environment can influence NPSO's internal capabilities.}

Due to the demand they represent, NPSOs have their capacity to acquire resources constrained by institutional environment. That is, the internal capacities of a NPSO is not freely affected by its resource acquisition capacity, but limited by the nature of agents' interests or environmental issues. It represents opportunities like the one stated by a sponsor: "some things we proposed were not smoothly accepted without validation from some influencers inside the organization" or when it is 
from the Corinthians marketing manager that "We cannot say that the (CBF's) work was not well done. It was not done at all. No one promotes Brazilian championship, nor Brazilian soccer clubs, nor Brazilian Brands."

\section{CONCLUSIONS, LIMITATIONS AND FUTURE RESEARCH SUGGESTIONS AND PRACTICAL IMPLICATIONS}

For Winand et al. (2014), future challenges for NPSOs is having to understand and explain high performance and this article is very suitable to contribute by including the role that institutional environment and Strategic Networks have in NPSO performance. Interviews' findings allow the construction of a model, which from the perspective of a single organization can state how the institutional environment and Strategic Networks formation impact on its performance.

Factors facilitating high performance include the team's resources and creating internal capabilities. In this sense, constructing partnerships allows higher levels of resources acquisitions that leads to high performances and generates a strong brand name. Moreover, the brand name increases teams position in institutional environment, which expands organization size facilitating entry in other networks.

The more networks a team belongs to, the more the team expands its size and the more resources the team acquires, increasing its capacities. A major contribution of this research in Strategic Network, considering this case, is that a way for a team to increase its size is by creating and operating different businesses as Corinthians does with its franchises.

In addition, by expanding its organization, Corinthians has secondary networks with nonprofit organizations. Another contribution to the Strategic Network is that as a firm, in this case a NPSO, it enters in different networks reinforcing the main network, in this case, the soccer business.

\section{Limitations and Future research suggestions}

By the own nature of the research, with temporal and physical boundaries, it was restricted to a single phenomenon in a specific centenarian organization. It is probable that further research can incorporate longitudinal perspective to interviewees' impressions and could differentiate slowmoving causal processes from fast-moving causal processes and discriminate incremental changes in the environment.

Moreover, the research could be extended to more sport clubs in Brazil to guarantee consistency among the scenario found in this particular organization compared to others.

Another limitation was regarding to the selected approach, which in one hand allows researchers to see "the big picture", and on the other hand misses the possibility to understand 
each of the variables that were collected in these macro dimensions more in-depth. For example, a researcher could focus in only one of the NPSO's internal capability.

\section{Practical Implications}

For Sports Management, this research contributes in the sense that in order for the Soccer Sports Organization to achieve success in terms of gaining games and championships, it has to either enter or create a Network.

Despite all limitations, this article has contributed to a better understanding of how the institutional environment and Strategic Networks influence a NPSO's performance, which helps to understand, analyze and measure organizational performance. Academics can benefit from a model that sees organizations embedded in networks, not considered in the reviewed literature and in the practical nature of sports management, and can profit from a better understanding of how NPSOs behave and the main factors that might be considered to enter networks and how to measure their performance. Due to space limitations, all interviews transcriptions are available for further consulting.

And for soccer fans it can be said, in addition, that it is very clear to state that becoming a world champion by itself does not turn the club into a world-class player.

\section{REFERENCES}

AHUJA, Gautam. Collaboration networks, structural holes, and innovation: A longitudinal study. Administrative science quarterly, v. 45, n. 3, p. 425-455, 2000.

AHUJA, Gautam; SODA, Giuseppe; ZAHEER, Akbar. The genesis and dynamics of organizational networks. Organization Science, v. 23, n. 2, p. 434-448, 2012.

AIKEN, K. Damon; CAMPBELL, Richard M.; KOCH, Eric C. Exploring the relationship between team (as brand) personality and geographic personality: linking consumer perceptions of sports teams and cities. International Journal of Sports Marketing and Sponsorship, v.15, n.1, p.2-14, 2013.

AUERBACH, Carl; SILVERSTEIN, Louise B. Qualitative data: An introduction to coding and analysis. NYU press, 2003.

BARNEY, Jay B.; KETCHEN, David J.; WRIGHT, Mike. The future of resource-based theory revitalization or decline?. Journal of management, v. 37, n. 5, p. 1299-1315, 2011.

BARONCELLI, Alessandro; LAGO, Umberto. Italian football. Journal of Sports Economics, v. 7, n. 1, p. 13-28, 2006.

BARROS, Carlos Pestana; SCAFARTO, Vincenzo; SAMAGAIO, António. Cost performance of Italian football clubs: analysing the role of marketing and sponsorship. International Journal of Sports Marketing and Sponsorship, v.15, n.4, p.59-77, 2014.

BASHIR, Muhammad; AFZAL, Muhammad Tanveer; AZEEM, Muhammad. Reliability and validity of qualitative and operational research paradigm. Pakistan Journal of statistics and operation research, v. 4, n. 1, 2008. 
BAUM, JoelAC; OLIVER, Christine. Institutional embeddedness and the dynamics of organizational populations. American Sociological Review, p. 540-559, 1992.

BAXTER, Pamela; JACK, Susan. Qualitative case study methodology: Study design and implementation for novice researchers. The qualitative report, v. 13, n. 4, p. 544-559, 2008.

BERRONE, Pascual. Business lessons from the soccer World Cup. Management Research: Journal of the Iberoamerican Academy of Management, v. 9, n. 1, p. 73-78, 2011.

BORGATTI, Stephen P.; HALGIN, Daniel S. On network theory. Organization Science, v. 22, n. 5 p. 1168-1181, 2011.

BRAMOULLÉ, Yann; KRANTON, Rachel; D'AMOURS, Martin. Strategic interaction and networks. The American Economic Review, v. 104, n. 3, p. 898-930, 2014.

CARPENTER, Mason A.; LI, Mingxiang; JIANG, Han. Social network research in organizational contexts a systematic review of methodological issues and choices. Journal of Management, $\mathrm{v}$. 38, n. 4: p. 1328-1361, 2012.

Chadwick, S.. Sports success and its influence on sports marketing. International Journal of Sports Marketing \& Sponsorship, v.8, n. 3, p. 205-220, 2007.

Chang, Y., Jae Ko, Y., Tasci, A., Arai, A., Kim, T.. Strategic match of athlete endorsement in global markets: an associative learning perspective. International Journal of Sports Marketing and Sponsorship, v.15, n.4, p. 40-58, 2014.

CLARKE, Irvine; MANNION, Ryan. Marketing sport to Asian-American consumers. Sport Marketing Quarterly, v. 15, n. 1, p. 20, 2006.

CHASSAGNON, Virgile. The network firm as a single real entity: beyond the aggregate of distinct legal entities. Journal of Economic Issues, v. 45, n. 1, p. 113-136, 2011.

CHRISTAKIS, Nicholas A. et al. An Empirical Model for Strategic Network Formation. NBER Working Paper Series, p. 16039, 2010.

COOKE, Mike; BUCKLEY, Nick. Web 2.0, social networks and the future of market research. International Journal of Market Research, v. 50, n. 2, p. 267, 2008.

CORINTHIANS, Relatório de Sustentabilidade 2014, Avaiable in http://www.corinthians.com.br/ upload/site/relatorio-de-sustentabilidade-2015.pdf. Acessed in February, 04, 2016

CRESPO, Joan; SUIRE, Raphael; VICENTE, Jerome. Lock-in or lock-out? How structural properties of knowledge networks affect regional resilience. Journal of Economic Geography, v. 14, n. 1, p. 199-219, 2014.

CRESWELL, John W.; MILLER, Dana L. Determining validity in qualitative inquiry. Theory into practice, v. 39, n. 3, p. 124-130, 2000.

CUTLER, M. Bundesliga international rights double. Retrieved from http://www.sportbusiness. com/news. 170896/bundesliga- international-rights-double, accessed in june 282016

DI MININ, Alberto et al. Udinese Calcio soccer club as a talents factory: Strategic agility, diverging objectives, and resource constraints. European Management Journal, v. 32, n. 2, p. 319-336, 2014.

DOWLING, Grahame R. Corporate reputations: Should you compete on yours?. California Management Review, v. 46, n. 3, p. 19-36, 2004. 
EISENHARDT, Kathleen M. Building theories from case study research. Academy of management review, v. 14, n. 4, p. 532-550, 1989.

EKLINDER-FRICK, Jens; ERIKSSON, Lars-Torsten; HALLÉN, Lars. Bridging and bonding forms of social capital in a regional strategic network. Industrial Marketing Management, v.40, n.6: p. 994-1003, 2011.

ESTRIDGE, H. L. Ranger owner talks sports business. Dallas Business Journal, 2007.

FIFA, 2014, 2014 FIFA World Cup Television Audience Report, Avaiable in: http://resources. fifa.com/mm/document/affederation/tv/02/74/55/57/2014fwcbraziltvaudiencereport(draft5) (issuedate14.12.15)_neutral.pdf

FURRER, Olivier; THOMAS, Howard; GOUSSEVSKAIA, Anna. The structure and evolution of the strategic management field: A content analysis of 26 years of strategic management research. International Journal of Management Reviews, v. 10, n. 1, p. 1-23.

GALASKIEWICZ, Joseph; ZAHEER, Akbar. Networks of competitive advantage. Research in the Sociology of Organizations, v. 16, n. 1, p. 237-61, 1999.

GARCIA-PONT, Carlos; NOHRIA, Nitin. Local versus global mimetism: The dynamics of alliance formation in the automobile industry. Strategic Management Journal, v. 23, n. 4, p. 307-321, 2002.

Gerring, John. What is a case study and what is it good for?. American political science review, v. 98, n. 02, p. 341-354, 2004.

GLASER, B. Strauss; STRAUSS, Anselm. A.(1967). The discovery of grounded theory. Strategies for qualitative research. London: Weidenfeld and Nicolson, 1968.

GOLAFSHANI, Nahid. Understanding reliability and validity in qualitative research. The qualitative report, v. 8, n. 4, p. 597-606, 2003.

GOLDMAN, Michael; JOHNS, Kate. Sportainment: changing the pace of limited-overs cricket in South Africa. Management Decision, v. 47, n. 1, p. 124-136, 2009.

GRANDORI, Anna; SODA, Giuseppe. Inter-firm networks: antecedents, mechanisms and forms. Organization studies, v. 16, n. 2, p. 183-214, 1995.

GROYSBERG, Boris; LEE, Linda-Eling; NANDA, Ashish. Can they take it with them? The portability of star knowledge workers' performance. Management Science, v. 54, n. 7, p. 1213$1230,2008$.

GULATI, Ranjay; NICKERSON, Jack A. Interorganizational trust, governance choice, and exchange performance. Organization Science, v. 19, n. 5, p. 688-708, 2008.

GULATI, Ranjay; LAVIE, Dovev; MADHAVAN, Ravindranath Ravi. How do networks matter? The performance effects of interorganizational networks. Research in Organizational Behavior, v. 31, p. 207-224, 2011.

Henseler, J., Wilson, B., Götz, O., Hautvast, C. Investigating the moderating role of fit on sports sponsorship and brand equity. International Journal of Sports Marketing and Sponsorship, v.8, n. 4, p.34-42, 2007.

HILL, John S.; VINCENT, John. Globalisation and sports branding: the case of Manchester United. International Journal of Sports Marketing and Sponsorship, v. 7, n. 3, p. 61-78, 2006. 
HODGETTS, Darrin James; STOLTE, Ottilie Emma Elisabeth. Case-based Research in Community and Social Psychology: Introduction to the Special Issue. Journal of Community \& Applied Social Psychology, v. 22, n. 5, p. 379-389, 2012.

JANG, Wonseok; JAE KO, Yong; CHAN-OLMSTED, Sylvia M. Spectator-based sports team reputation: scale development and validation. International Journal of Sports Marketing and Sponsorship, v. 16, n. 3, p. 52-72, 2015.

JANSSON, Johan; MARELL, Agneta; NORDLUND, Annika. Green consumer behavior: determinants of curtailment and eco-innovation adoption. Journal of consumer marketing, v. 27, n. 4, p. 358-370, 2010.

JARILLO, J. Carlos. On strategic networks. Strategic management journal, v. 9, n. 1, p. 31-41, 1988.

JOHANSON, Jan; VAHLNE, Jan-Erik. The Uppsala internationalization process model revisited: From liability of foreignness to liability of outsidership. Journal of international business studies, v. 40, n. 9, p. 1411-1431, 2009.

KEH, Hean Tat; XIE, Yi. Corporate reputation and customer behavioral intentions: The roles of trust, identification and commitment. Industrial Marketing Management, v. 38, n. 7, p. 732-742, 2009.

KELLER, Kevin Lane; PARAMESWARAN, M. G.; JACOB, Isaac. Strategic brand management: Building, measuring, and managing brand equity. Pearson Education India, 2011.

KLIJN, Erik-Hans; EDELENBOS, Jurian; STEIJN, Bram. Trust in governance networks its impacts on outcomes. Administration \& Society, v. 42, n. 2, p. 193-221, 2010.

KNOX, Sarah; BURKARD, Alan W. Qualitative research interviews. Psychotherapy Research, v. 19, n. 4-5, p. 566-575, 2009.

KOZLENKOVA, Irina V.; SAMAHA, Stephen A.; PALMATIER, Robert W. Resource-based theory in marketing. Journal of the Academy of Marketing Science, v. 42, n. 1, p. 1-21, 2014.

KRAAIJENBRINK, Jeroen; SPENDER, J.-C.; GROEN, Aard J. The resource-based view: a review and assessment of its critiques. Journal of management, v. 36, n. 1, p. 349-372, 2010.

LANZA, Andrea; SIMONE, Giuseppina; BRUNO, Randolph. Resource orchestration in the context of knowledge resources acquisition and divestment. The empirical evidence from the Italian "Serie A” football. European Management Journal, v. 34, n. 2, p. 145-157, 2016.

LANGE, Donald; LEE, Peggy M.; DAI, Ye. Organizational reputation: A review. Journal of Management, v. 37, n. 1, p. 153-184, 2011.

LEWIS, Michael. Franchise relocation and fan allegiance. Journal of Sport \& Social Issues, v. 25, n. 1, p. 6-19, 2001.

MACKINNON, Danny. Beyond strategic coupling: reassessing the firm-region nexus in global production networks. Journal of Economic Geography, v. 12, n. 1, p. 227-245, 2012.

MARIOTTI, Francesca; DELBRIDGE, Rick. Overcoming network overload and redundancy in interorganizational networks: The roles of potential and latent ties. Organization Science, v. 23, n. 2, p. 511-528, 2012.

MARSHALL, Martin N. Sampling for qualitative research. Family practice, v. 13, n. 6, p. 522-526, 1996. 
MAS-RUIZ, Francisco; RUIZ-MORENO, Felipe. Rivalry within strategic groups and consequences for performance: the firm-size effects. Strategic Management Journal, v. 32, n. 12, p. 1286-1308, 2011.

MCWILLIAMS, Abagail; SIEGEL, Donald S. Creating and Capturing Value Strategic Corporate Social Responsibility, Resource-Based Theory, and Sustainable Competitive Advantage. Journal of Management, v. 37, n. 5, p. 1480-1495, 2011.

MERCIER, Hugo; SPERBER, Dan. Why do humans reason? Arguments for an argumentative theory. Behavioral and brain sciences, v. 34, n. 02, p. 57-74, 2011.

MILLAR, Patti; DOHERTY, Alison. Capacity building in nonprofit sport organizations: Development of a process model. Sport Management Review, 2016.

MORSE, Janice M. et al. Verification strategies for establishing reliability and validity in qualitative research. International journal of qualitative methods, v. 1, n. 2, p. 13-22, 2002.

MUNIZ, Albert M.; O'GUINN, Thomas C. Brand community. Journal of consumer research, v. 27, n. 4, p. 412-432, 2001.

OWEN-SMITH, Jason; POWELL, Walter W. Networks and institutions. The Sage handbook of organizational institutionalism, p. 596-623, 2008.

PARENT, Milena M.; FOREMAN, Peter, O. "Organizational image and identity management in large-scale sporting events.” Journal of Sport Management, v. 21, n.1, p.15-26, 2007.

PARENT, Milena M.; SÉGUIN, Benoit. Toward a model of brand creation for international largescale sporting events: The impact of leadership, context, and nature of the event. Journal of Sport Management, v.22, n.5, p.526-549, 2008.

PETTIGREW, Andrew M. Longitudinal field research on change: Theory and Practice. Organization science, v. 1, n. 3, p. 267-292, 1990.

PHELPS, Corey C. A longitudinal study of the influence of alliance network structure and composition on firm exploratory innovation. Academy of Management Journal, v. 53, n. 4, p. 890-913, 2010.

PLATT, Jennifer. "Case study” in American methodological thought. Current Sociology, v. 40, n. 1, p. 17-48, 1992.

PODOLNY, Joel M. A status-based model of market competition. American journal of sociology, p. 829-872, 1993.

PAWLOWSKI, Tim; ANDERS, Christoph. Stadium attendance in German professional footballThe (un) importance of uncertainty of outcome reconsidered. Applied Economics Letters, v. 19, n. 16, p. 1553-1556, 2012.

PYUN, Do Young; KWON, Hyungil H.; LEE, Chul-Won. The influences of perceived brand quality and ethnocentrism on consumption patterns of a global sports brand: the case of Korean college students. International Journal of Sports Marketing and Sponsorship, v.13, n.1, p.18-32, 2011.

RATTEN, Vanessa. Practical implications and future research directions for international sports management. Thunderbird international business review, v. 53, n. 6, p. 763-770, 2011.

RICHELIEU, André; DESBORDES, Michel. Football teams going international-the strategic leverage of branding. Journal of Sponsorship, v. 3, n. 1, p. 10-22, 2009.

ROCHA, Claudio M.; FINK, Janet S. Patriotism, national athletes and intention to purchase international sports products. International Journal of Sports Marketing and Sponsorship, v.16, n.2, p.57-71, 2015. 
SIMONS, Helen. The paradox of case study. Cambridge Journal of Education, v. 26, n. 2, p. $225-$ 240, 1996.

SOOSAY, Claudine et al. Strategies for sustaining manufacturing competitiveness: comparative case studies in Australia and Sweden. Journal of Manufacturing Technology Management, v. 27, n. 1, p. 6-37, 2016.

STAKE, Robert E. The art of case study research. Sage, 1995.

STRIJBOS, Jan-Willem et al. Content analysis: What are they talking about? Computers \& Education, v. 46, n. 1, p. 29-48, 2006.

SUNG, Yongjun; KIM, Jooyoung. Effects of brand personality on brand trust and brand affect. Psychology \& Marketing, v. 27, n. 7, p. 639-661, 2010.

SURI, Harsh. Purposeful sampling in qualitative research synthesis. Qualitative Research Journal, V. 11, n. 2 , p. $63-75,2011$.

SWANBORN, Peter. Case study research: what, why and how?. Sage, 2010.

TADELIS, Steven; WILLIAMSON, Oliver E. Transaction cost economics. Available at SSRN $2020176,2012$.

TRAIL, Galen T.; KIM, Yu Kyoum. Factors influencing spectator sports consumption: NCAA women's college basketball. International Journal of Sports Marketing and Sponsorship, v.13, n.1, p. 55-77, 2011.

WALSH, Gianfranco; BEATTY, Sharon E.; SHIU, Edward MK. The customer-based corporate reputation scale: Replication and short form. Journal of Business Research, v. 62, n. 10, p. $924-$ 930, 2009.

WATT, Diane. On Becoming a Qualitative Researcher: The Value of Reflexivity. Qualitative Report, v. 12, n. 1, p. 82-101, 2007.

WILLIAMSON, Oliver E. Transaction cost economics: The natural progression. Journal of Retailing, v. 86, n. 3, p. 215-226, 2010.

WINAND, Mathieu et al. A unified model of non-profit sport organizations performance: perspectives from the literature. Managing Leisure, v. 19, n. 2, p. 121-150, 2014.

ZAHEER, Akbar; GULATI, Ranjay; NOHRIA, Nitin. Strategic networks. Strategic management journal, v. 21, n. 3, p. 203, 2000.

ZAHEER, Akbar; BELL, Geoffrey G. Benefiting from network position: firm capabilities, structural holes, and performance. Strategic management journal, v. 26, n. 9, p. 809-825, 2005.

ZAHEER, Akbar; GÖZÜBÜYÜK, Remzi; MILANOV, Hana. It's the connections: The network perspective in interorganizational research. The Academy of Management Perspectives, v. 24, $\mathrm{n}$. 1, p. 62-77, 2010.

ZHANG, James J.; KIM, Minhong; PIFER, N. David. IMPORTANCE OF THEORY IN QUANTITATIVE ENQUIRY. Routledge Handbook of Theory in Sport Management, 2015.

ZHOU, Lianxi; TENG, Lefa; POON, Patrick S. Susceptibility to global consumer culture: A threedimensional scale. Psychology \& Marketing, v. 25, n. 4, p. 336-351, 2008. 